\title{
FOXP3 Expression in GARP-Transduced Helper T Cells Is Not Associated with FOXP3 TSDR Demethylation
}

\author{
Jan Kehrmann ${ }^{\mathrm{a}} \quad$ Michael Zeschnigk $^{\mathrm{b}} \quad$ Jan Buer $^{\mathrm{a}} \quad$ Michael Probst-Kepper $^{\mathrm{c}}$ \\ ${ }^{a}$ Institut für Medizinische Mikrobiologie, \\ ${ }^{\mathrm{b}}$ Institut für Humangenetik, Universitätsklinikum Essen, Universität Duisburg-Essen, Essen, \\ ${ }^{c}$ Institut für Mikrobiologie, Immunologie und Krankenhaushygiene, Städtisches Klinikum Braunschweig gGmbH, Braunschweig, Germany
}

\section{Keywords}

Regulatory T cells · FOXP3 - GARP · LRRC32 . TSDR

\section{Summary}

Aim: Glycoprotein A repetitions predominant (GARP or LRRC32) represents a human regulatory $C D 4+C D 25^{\text {hi }}$ FOXP3+ $\mathrm{T}\left(\mathrm{T}_{\text {reg }}\right)$ cell-specific receptor that controls FOXP3. Ectopic expression of GARP in helper $T\left(T_{h}\right)$ cells has been shown to be sufficient for the induction of FOXP3 and generation of a stable regulatory phenotype. Since expression of FOXP3 in $\mathrm{T}_{\text {reg }}$ cells is epigenetically controlled by a conserved motif, the so-called $\mathrm{T}_{\text {reg-spe- }}$ cific demethylated region (TSDR), we asked whether GARP-mediated upregulation of FOXP3 in $T_{h}$ cells is similarly accompanied by demethylation of the TSDR. Methods: DNA methylation of the FOXP3 TSDR was analyzed by direct sequencing of polymerase chain reaction (PCR) products from bisulfite-treated genomic DNA. Results: Although GARP-transduced $T_{h}$ cells exhibit constitutive FOXP3 expression and a regulatory phenotype, the FOXP3 TSDR is completely methylated as in naive $T_{h}$ cells. GARP-mediated FOXP3 upregulation in $T_{h}$ cells is not associated with $T_{\text {reg }}$-specific demethylation of the FOXP3 TSDR. Conclusion: Although GARP-engineered $\mathrm{T}_{\mathrm{h}}$ cells exhibit stable FOXP3 expression and a phenotypic reprogramming towards $\mathrm{T}_{\text {reg }}$ cells in vitro, these cells do not completely mimic the epigenotype of natural $T_{\text {reg }}$ cells. Thus, concepts based on the genetic modification of $T_{h}$ cells as cellular therapies to treat autoimmune diseases or to control transplantation tolerance should be critically tested before any clinical application.

\section{Schlüsselwörter}

Regulatorische T-Zellen · FOXP3 - GARP · LRRC32 • TSDR

\section{Zusamenfassung}

Hintergrund: Glycoprotein A repetitions predominant (GARP, LRRC32) ist ein spezifischer Rezeptor von humanen, regulatorischen CD4+CD25 ${ }^{\text {hi }}$ FOXP3 $+T\left(T_{\text {reg }}\right)$-Zellen, welcher FOXP3 kontrolliert. So konnte gezeigt werden, dass die ektope Expression von GARP in T-Helfer $\left(T_{h}\right)$ Zellen ausreichend für die Induktion von FOXP3 und einem stabilen regulatorischen Phänotyp ist. Da die Expression von FOXP3 in $\mathrm{T}_{\text {reg }}$-Zellen epigenetisch durch ein konserviertes genomisches Motiv, die $" \mathrm{~T}_{\text {reg }}$-specific demethylated region" (TSDR), kontrolliert wird, stellt sich uns die Frage, ob die GARP-induzierte Expression von FOXP3 in $\mathrm{T}_{\mathrm{h}}$-Zellen ebenfalls von einer Demethylierung der TSDR begleitet ist. Methoden: Die DNA-Methylierung der TSDR wurde durch direkte Sequenzierung von $\mathrm{PCR}$ (polymerase chain reaction)-Produkten Bisulfit-behandelter genomischer DNA von GARP-, FOXP3-, und Kontroll-transduzierten $\mathrm{T}_{\mathrm{h}}$-Zellen im Vergleich zu natürlichen

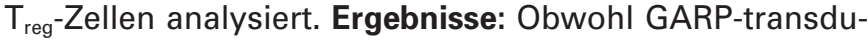
zierte $T_{h}$-Zellen eine konstitutive FOXP3-Expression und einen regulatorischen Phänotyp aufweisen, ist die FOXP3 TSDR wie in normalen $\mathrm{T}_{\mathrm{h}}$-Zellen komplett methyliert. Die GARP-vermittelte FOXP3-Induktion in $\mathrm{T}_{\mathrm{h}}$-Zellen ist nicht

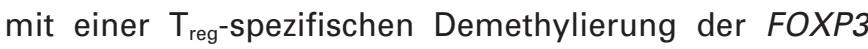
TSDR verbunden. Schlussfolgerung: Obwohl durch GARP-veränderte $T_{h}$-Zellen in vitro eine stabile FOXP3Expression mit einer phänotypischen Reprogrammierung

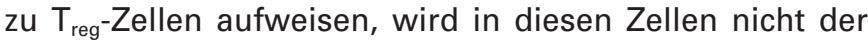
komplette Epigenotyp von natürlichen $\mathrm{T}_{\text {reg }}$-Zellen erreicht. Aus diesem Grund sollten Therapiekonzepte basierend auf der genetischen Modifikation von $\mathrm{T}_{\mathrm{h}}$-Zellen zur Behandlung von Autoimmunerkrankungen oder der Kontrolle einer Transplantationstoleranz einer kritischen Untersuchung vor der klinischen Anwendung unterliegen.

\section{KARGER}

Fax +497614520714

Information@Karger.de

www.karger.com (c) 2011 S. Karger GmbH, Freiburg

Accessible online at:

www.karger.com/tmh
Dr. Michael Probst-Kepper

Institut für Mikrobiologie, Immunologie und Krankenhaushygiene

Städtisches Klinikum Braunschweig gGmbH

Celler Straße 38, 38114 Braunschweig, Germany

Tel. +49 531 595-3763, Fax -3498

m.probst-kepper@klinikum-braunschweig.de 


\section{Introduction}

The forkhead box protein P3 (FOXP3) is a transcription factor essential for the development and function of CD4+ $\mathrm{CD} 25^{\text {hi }}$ regulatory $\mathrm{T}\left(\mathrm{T}_{\text {reg }}\right)$ cells. FOXP3 $+\mathrm{T}_{\text {reg }}$ cells are an essential component for the maintenance of tolerance in transplantation and autoimmunity. Thus, isolation and expansion of natural $\mathrm{T}_{\text {reg }}$ cells or their design via molecular engineering of antigen-specific $\mathrm{T}$ cells for regulatory $\mathrm{T}$ cell therapies represent a major focus for adoptive $\mathrm{T}$ cell transfer concepts in different disease settings [1,2]. The molecular mechanism maintaining stable FOXP3 expression in $\mathrm{T}_{\text {reg }}$ cells has been elucidated recently by the identification of an evolutionarily conserved region with $\mathrm{CpG}$ motifs within the non-coding part of the gene. This genomic region is completely unmethylated in $T_{\text {reg }}$ cells but methylated in naive and effector $T$ cells and thus has been designated the $\mathrm{T}_{\text {reg }}$-specific demethylated region $(T S D R)$ [3-6]. The significance of this epigenetic marker is obvious, because the methylation status of the FOXP3 gene is an even better marker of suppressor function than the differential expression of FOXP3 at the mRNA or protein level $[7,8]$. Moreover, $4 \mathrm{CpG}$ motifs within the TSDR have been identified as binding sites for essential transcription factors, such as CREB/ATF, NF-кB, and Ets-1. Ets-1 binds only to the unmethylated $T S D R$, a finding suggesting that restricted binding of a transcription factor complex controls stable FOXP3 expression in $\mathrm{T}_{\text {reg }}$ cells [9]. Therefore, the $T S D R$ is an essential control region and marker of natural $\mathrm{T}_{\text {reg }}$ cells.

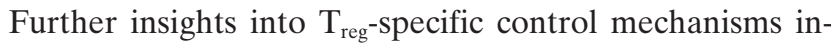
volved in the maintenance of sustained high levels of FOXP3 have been recently gained with the characterization of glycoprotein A repetitions predominant (GARP or LRRC32) [10-14] (reviewed in [2]). GARP is a $\mathrm{T}_{\text {reg }}$-specific protein that is induced after T-cell receptor (TCR) activation and controls FOXP3 via a positive feedback loop [10, 12, 15]. Moreover, GARP functions as a cell surface receptor for latency-associated peptide (LAP)/latent transforming growth factor $\beta$ (TGF- $\beta$ ) $[13,14]$ (reviewed in [16]). $\mathrm{T}_{\text {reg-specific expression of }}$ GARP has been corroborated by the identification of a genomic region in intron 1 of GARP with a $T_{\text {reg }}$ cell-specific hypomethylation [17]. This finding suggests lineage-specific transcription of GARP in $\mathrm{T}_{\text {reg }}$ cells similar to FOXP3. More importantly, retroviral overexpression of GARP in helper $\mathrm{T}$ $\left(\mathrm{T}_{\mathrm{h}}\right)$ cells leads to an efficient and stable reprogramming of effector $\mathrm{T}$ cells into $\mathrm{T}_{\text {reg }}$ cells, and this reprogramming is associated with the induction of the constitutive expression of FOXP3 and a regulatory phenotype [10,12].

In the murine system, partial demethylation of the FOXP3 locus has been observed in CD4+ CD25- FoxP3- T cells activated in the presence of TGF- $\beta$. This partial demethylation is associated with the upregulation of FoxP3, a finding suggesting that the epigenetic control of murine FoxP3 is mediated by external stimuli that manipulate $\mathrm{T}$ cell fate [3].
Recently it has been demonstrated that peroxisome proliferator-activated receptor $\alpha(\operatorname{PPAR} \alpha)$ and PPAR $\gamma$ agonists, in combination with TGF- $\beta$, induce demethylation of the FOXP3 locus in human peripheral CD4+ CD25- $\mathrm{T}_{\mathrm{h}}$ cells through a downregulation of DNA methyltransferases. This demethylation leads to the stable expression of FOXP3, which results in the generation of functional induced $\mathrm{T}_{\text {reg }}$ cells [18].

Since GARP represents a potential tool to engineer disease-associated $\mathrm{T}_{\mathrm{h}}$ cells to generate FOXP3-expressing regulatory $\mathrm{T}$ cells for regulatory $\mathrm{T}$ cell therapies [2], the critical risk-benefit assessment for such an approach remains whether stable regulatory functions of GARP-engineered $\mathrm{T}_{\mathrm{h}}$ cells observed in vitro would persist after adoptive $\mathrm{T}$ cell transfer in vivo. Based on the clear association of TSDR demethylation, which permits constitutive expression of FOXP3 and stable regulatory function of natural $\mathrm{T}_{\text {reg }}$ cells, our hypothesis was that analysis of TSDR would enable such a risk-benefit assessment. For this reason we analyzed TSDR-methylation of GARP-transduced $T_{h}$ cells, characterized by $T_{\text {reg }}$-like FOXP3 expression and stable regulatory function and FOXP3-trans-

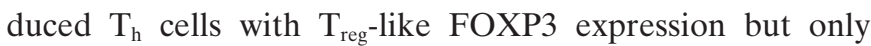
partial regulatory function compared to control-transduced $\mathrm{T}_{\mathrm{h}}$ cells and natural $\mathrm{T}_{\text {reg }}$ cells. In the case of $\mathrm{T}_{\text {reg }}$-like TSDR epigenotype in GARP-transduced $\mathrm{T}_{\mathrm{h}}$ cells, the hypothesis of having guaranteed stable regulatory function of such cells in vivo would have been confirmed.

\section{Material and Methods}

\section{T Cells}

The $\mathrm{T}$ cells analyzed have recently been extensively described and characterized $[12,15,19,20]$. In brief, CD4+CD25- $\mathrm{T}_{\mathrm{h}}$ cells and CD4+CD25 $5^{\mathrm{hi}}$ $\mathrm{T}_{\text {reg }}$ cells were sorted from a healthy donor and stimulated weekly with the allogeneic Epstein-Barr virus (EBV) B-cell line LG2 EBV to generate alloreactive $\mathrm{T}_{\mathrm{h}}$ cells (CD4-39) and $\mathrm{T}_{\text {reg }}$ cells $\left(\mathrm{T}_{\text {reg }} \mathrm{HG}\right.$ and $\mathrm{T}_{\text {reg }} \mathrm{THU}$ ) [19]. $T_{h}$ cells were transduced with a retrovirus expressing either GARP or FOXP3 coupled with an IRES-driven green fluorescent protein (GFP) ( $\mathrm{T}_{\mathrm{h}}$ GARP and $\mathrm{T}_{\mathrm{h}} \mathrm{FOXP3}$, respectively) and the empty IRES-GFP vector $\left(T_{h}\right.$ GFP). Transduced cells were sorted for GFP expression, cultured further in the same manner, and extensively characterized by functional, transcriptional, and protein expression analyses, as previously described $[12,15]$.

\section{Immunostaining}

For cell surface immunostaining, PE- and APC-conjugated monoclonal antibodies (mAbs) against CD25, CD27, CD83, and CD33 with respective isotype-control Abs were used (all from BD Bioscience, San Jose, CA, USA). For intracellular immunostaining, Alexa Fluor 467-conjugated mAb against FOXP3 (206D) and respective isotype control (MOPC; BioLegend Inc., San Diego, CA, USA) were used according to the manufacturer's instructions.

\section{DNA Isolation and Methylation Analysis}

DNA isolation was performed with the QIAamp DNA Mini Kit (Qiagen, Hilden, Germany) according to the manufacturer's guidelines. Bisulfite modification of DNA was performed according to an established protocol with minor modifications [21]. Genomic DNA (1-2 $\mu \mathrm{g}$ in $50 \mu \mathrm{l})$ was denatured for $15 \mathrm{~min}$ at $37{ }^{\circ} \mathrm{C}$ by adding $5.5 \mu \mathrm{l}$ of $3 \mathrm{~mol} / \mathrm{l}$ sodium hydroxide 
A
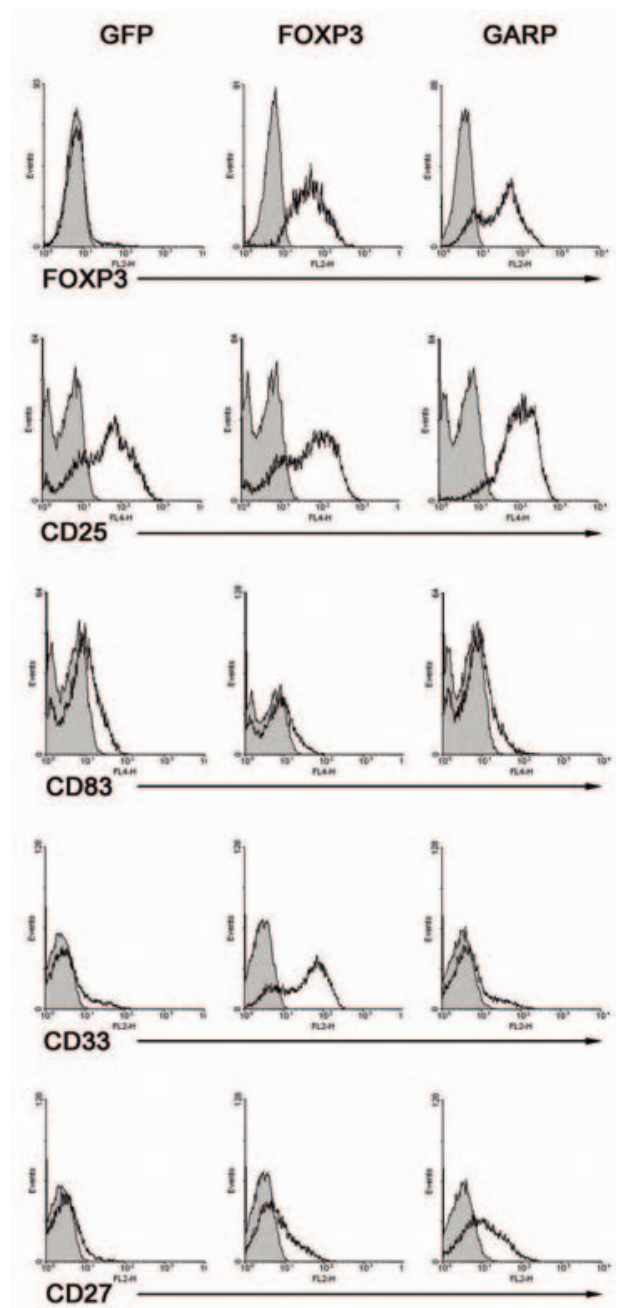

(NaOH). For complete denaturation, samples were incubated at $95{ }^{\circ} \mathrm{C}$ for 2 min and immediately cooled on ice. The bisulfite solution was freshly prepared by dissolving $4.25 \mathrm{~g}$ of sodium bisulfite (Sigma-Aldrich, St. Louis, MO, USA) in $7.5 \mathrm{ml} \mathrm{H}{ }_{2} \mathrm{O}$. Next, $450 \mu \mathrm{l}$ of $50 \mathrm{mmol} / \mathrm{l}$ hydrochinone solution was added, and the $\mathrm{pH}$ was adjusted to 5.15 by the addition of $500 \mu \mathrm{l}$ of 10 mol/l NaOH. The denatured DNA solution was mixed with $1 \mathrm{ml}$ of the bisulfite solution and incubated in the dark at $50^{\circ} \mathrm{C}$ for $16-20 \mathrm{~h}$. The DNA was recovered by using the Wizard DNA Clean-Up System (Promega Corp., Madison, WI, USA) followed by elution in $50 \mu 1 \mathrm{H}_{2} \mathrm{O}(65$ ${ }^{\circ} \mathrm{C}$ ). Subsequently, $5.5 \mu \mathrm{l}$ of $3 \mathrm{~mol} / \mathrm{l} \mathrm{NaOH}$ was added, and the samples were incubated for $15 \mathrm{~min}$ at $37{ }^{\circ} \mathrm{C}$. The solution was then neutralized by adding $55 \mu \mathrm{l}$ of $6 \mathrm{~mol} / \mathrm{l}$ ammonium acetate $\left(\mathrm{NH}_{4} \mathrm{OAc}\right), \mathrm{pH}$ 7.0. The DNA was precipitated with ethanol, washed in $70 \%$ ethanol, dried, and resuspended in 15 to $30 \mu \mathrm{l}$ of water, depending on the initial DNA input. The regions of interest were analyzed by polymerase chain reaction (PCR) using primers that specifically amplify bisulfite-treated DNA of the TSDR of FOXP3 (Foxp3Amp5fw: CTT GCT TCC TGG CAC GAG TGT TTG GGG GTA GAG GAT TT and Foxp3Amp5rev: TGT AAA ACG ACG GCC AGT TAT CAC CCC ACC TAA ACC AA, modified from Baron et al. [22]. The later direct sequence analysis of PCR products was facilitated by the use of PCR tag primers containing additional nucleotides at the 5 end that do not bind to the template and thus compensate for the missing base in PCR products from unmethylated samples during sequence analysis. PCR was performed with a GeneAmp 9700 system (Applied Biosystems, Foster City, CA, USA) in a total volume of $25 \mu$ l containing $3 \mu \mathrm{l}$ of bisulfite-treated DNA, $0.2 \mathrm{mmol} / \mathrm{l}$ of each $\mathrm{dNTP}, 0.8 \mu \mathrm{mol} / \mathrm{l}$ of each primer, $2.5 \mu \mathrm{l}$ of $10 \times$ PCR buffer, $2.5 \mathrm{mmol} / \mathrm{l}$ magnesium chloride $\left(\mathrm{MgCl}_{2}\right)$, and 0.5 U Taq Polymerase (AmpliTaq Gold, Applied Biosystems). A touchdown protocol was adopted as follows [23]: after denaturation at $95{ }^{\circ} \mathrm{C}$ for $5 \mathrm{~min}$, the annealing temperature was decreased by $0.5^{\circ} \mathrm{C}$ every cycle from $63{ }^{\circ} \mathrm{C}$ to $56{ }^{\circ} \mathrm{C}$, at which temperature 35 cycles were carried out. For all cycles, annealing was performed for $1 \mathrm{~min}$, denaturation at $95^{\circ} \mathrm{C}$ for $20 \mathrm{~s}$, and extension at $72{ }^{\circ} \mathrm{C}$ for $1 \mathrm{~min}$, followed by a final extension at $72{ }^{\circ} \mathrm{C}$ for $5 \mathrm{~min}$. After agarose gel electrophoresis and purification of the PCR products with the MinElute ${ }^{\mathrm{TM}}$ Gel Extraction Kit (Qiagen), sequence analysis was performed with an ABI PRISM 3100 automated capillary genetic analyzer (Applied Biosystems, Carlsbad, CA, USA) using Big Dye 1.1 (ABI, Applied Biosystems) and a primer binding to the tag sequence. The sequence files were further analyzed with Geneious Pro 5.3.4. A cytosine was classified as fully methylated if the A signal was absent or very low at scattered positions, as unmethylated in the absence of a $\mathrm{G}$ signal, and as partially methylated if both signals were present.

\section{Results and Discussion}

We analyzed the methylation status of the FOXP3 TSDR in alloreactive $T_{h}$ cells that had been transduced with GARP $\left(T_{h}\right.$ GARP) or FOXP3 $\left(T_{h} F O X P 3\right)$ coupled to an IRES-driven GFP or GFP alone $\left(\mathrm{T}_{\mathrm{h}} \mathrm{GFP}\right)$ [12]. These cells differ in many aspects, as described recently [12]. In brief, $\mathrm{T}_{\mathrm{h}} \mathrm{GARP}$ cells show $\mathrm{T}_{\text {reg }}$-like sustained FOXP3 expression (fig. 1A), an extended $\mathrm{T}_{\mathrm{reg}}$-mRNA signature, and $\mathrm{T}_{\mathrm{reg}}$-specific function (reviewed in [15]). In contrast, $\mathrm{T}_{\mathrm{h}}$ cells transduced with GFP alone exhibited an effector $\mathrm{T}$ cell phenotype and limited FOXP3 expression. $\mathrm{T}_{\mathrm{h}} \mathrm{FOXP} 3$ cells lie somewhere between these 2 extreme phenotypes, because they exhibit high levels of FOXP 3 expression and an extended $\mathrm{T}_{\text {reg }}$-mRNA signature but also unstable or minor regulatory function. 
The methylation status of all CpGs of FOXP3 TSDR was analyzed in $\mathrm{T}_{\mathrm{h}}$ GARP, $\mathrm{T}_{\mathrm{h}}$ FOXP3, and $\mathrm{T}_{\mathrm{h}} \mathrm{GFP}$ cells and revealed a fully methylated $T S D R$ in all cases (fig. $1 \mathrm{~B}$ ). In contrast, $\mathrm{T}_{\text {reg }}$ cells showed a typical largely unmethylated TSDR (fig. $1 \mathrm{~B}$ ). Thus, neither the stable expression of FOXP3 nor the regulatory function of GARP-transduced $\mathrm{T}_{\mathrm{h}}$ cells in vitro depends on an unmethylated $\mathrm{T}_{\text {reg }}$-like FOXP3 TSDR despite a phenotypic transdifferentiation towards $T_{\text {reg }}$ cells. Because GARP transduction does not influence the epigenotype at the FOXP3 TSDR, which is regarded as a specific and reliable marker of natural $\mathrm{T}_{\text {reg }}$ cells and their suppressor function [8], GARP-transduced $T_{h}$ cells do not perfectly mimic $T_{\text {reg }}$ cells, and thus our hypothesis that a TSDR epigenotype of GARPtransduced $T_{h}$ cells might guarantee their stable regulatory function in vivo has to be rejected.

Interestingly, in transdifferentiation studies of pluripotency, incomplete demethylation of genes has been shown to be characteristic of incompletely reprogrammed cells [24]. Therefore, FOXP3 TSDR methylation may be regarded as a marker of incomplete transdifferentiation of $T_{h}$ GARP cells. Consequently, concepts of GARP $[10,12]$ or FOXP3 transduction [25] of $\mathrm{T}_{\mathrm{h}}$ cells for cellular therapies to treat autoimmune diseases or control transplantation tolerance [2] should be critically tested before any clinical application to ensure stable regulatory function before adoptive transfer of such engineered $\mathrm{T}$ cells and to exclude potential hazardous reversion of a potentially disease-controlling regulatory to- wards a diseases-aggravating effector phenotype. Despite the encouraging preclinical results in many mouse models using either FOXP3 itself [26, 27] or FOXP3-regulating genes like GPR83 [28, 29] and CD83 [30] to generate regulatory $\mathrm{T}$ cells for adoptive transfer, based on the known differences between FOXP3 expression of $\mathrm{T}_{\text {reg }}$ cells in mice and man [31], critical risk-benefit assessment of such cellular therapies to ensure safe clinical application is of utmost importance.

In summary, ectopic expression of GARP in $T_{h}$ cells can induce sustained FOXP3 expression and a stable regulatory phenotype in vitro similar to that of $\mathrm{T}_{\text {reg }}$ cells. However, this phenotypic transformation is not reflected by a $T_{\text {reg }}$-specific demethylation of the TSDR raising serious questions about the stability of such engineered $\mathrm{T}$ cells for cellular therapies to treat autoimmune diseases or control transplantation tolerance in vivo.

\section{Acknowledgments}

This work was supported in part by grants from the Mercator-Stiftung.

\section{Disclosure Statement}

The authors declared no conflict of interest.

\section{References}

1 Miyara M, Wing K, Sakaguchi S: Therapeutic approaches to allergy and autoimmunity based on FoxP3+ regulatory T-cell activation and expansion. J Allergy Clin Immunol 2009;123:749-55.

- 2 Probst-Kepper M, Kröger A, Garritsen HSP, Buer $\mathrm{J}$ : Perspectives on regulatory $\mathrm{T}$ cell therapies. Transfus Med Hemother 2009;36:302-8.

$>3$ Floess S, Freyer J, Siewert C, Baron U, Olek S, Polansky J, Schlawe K, Chang HD, Bopp T, Schmitt E, Klein-Hessling S, Serfling E, Hamann A, Huehn $\mathrm{J}$ : Epigenetic control of the foxp3 locus in regulatory T cells. PLoS Biol 2007;5:e38.

$\checkmark 4$ Janson PC, Winerdal ME, Marits P, Thorn M, Ohlsson R, Winquist O: FOXP3 promoter demethylation reveals the committed Treg population in humans. PLoS ONE 2008;3:e1612.

5 Huehn J, Polansky JK, Hamann A: Epigenetic control of FOXP3 expression: the key to a stable regulatory T-cell lineage? Nat Rev Immunol 2009;9: $83-9$.

6 Liu J, Lluis A, Illi S, Layland L, Olek S, von Mutius E, Schaub B: T regulatory cells in cord blood - FOXP3 demethylation as reliable quantitative marker. PLoS ONE 2010;5:e13267.

7 Stockis J, Fink W, Francois V, Connerotte T, de Smet C, Knoops L, van der Bruggen P, Coulie PG, Lucas S: Comparison of stable human Treg and Th clones by transcriptional profiling. Eur J Immunol 2009;39:869-82.
François V, Ottaviani S, Renkvist N, Stockis J, Schuler G, Thielemans K, Colau D, Marchand M, Boon T, Lucas S, van der Bruggen P: The CD4+ T-cell response of melanoma patients to a MAGEA3 peptide vaccine involves potential regulatory T cells. Cancer Res 2009;69:4335-45.

$\checkmark$ Polansky JK, Schreiber L, Thelemann C, Ludwig L, Kruger M, Baumgrass R, Cording S, Floess S, Hamann A, Huehn J: Methylation matters: binding of Ets-1 to the demethylated Foxp3 gene contributes to the stabilization of Foxp3 expression in regulatory T cells. J Mol Med 2010;88:1029-40.

10 Wang R, Wan Q, Kozhaya L, Fujii H, Unutmaz $\mathrm{D}$ : Identification of a regulatory $\mathrm{T}$ cell specific cell surface molecule that mediates suppressive signals and induces Foxp3 expression. PLoS One 2008;3:e27705.

11 Wang R, Kozhaya L, Mercer F, Khaitan A, Fujii H, Unutmaz D: Expression of GARP selectively identifies activated human FOXP3+ regulatory $\mathrm{T}$ cells. Proc Natl Acad Sci U S A 2009;106:13439-44.

12 Probst-Kepper M, Geffers R, Kröger A, Viegas N, Erck C, Hecht HJ, Lünsdorf H, Roubin R, Moharregh-Khiabani D, Wagner K, Ocklenburg F, Jeron A, Garritsen H, Arstila TP, Kekäläinen E, Balling R, Hauser H, Buer J, Weiss S: GARP: a key receptor controlling FOXP3 in human regulatory T cells. J Cell Mol Med 2009;13:3343-57.

13 Stockis J, Colau D, Coulie PG, Lucas S: Membrane protein GARP is a receptor for latent TGF- $\beta$ on the surface of activated human Treg. Eur J Immunol 2009;39:3315-22.
4 Tran DQ, Andersson J, Wang R, Ramsey H, Unutmaz D, Shevach EM: GARP (LRRC32) is essential for the surface expression of latent TGF- $\beta$ on platelets and activated FOXP3+ regulatory T cells. Proc Natl Acad Sci U S A 2009;106:13445-50.

15 Probst-Kepper M, Balling R, Buer J: FOXP3: required but not sufficient. the role of GARP (LRRC32) as a safeguard of the regulatory phenotype. Curr Mol Med 2010;10:533-9.

16 Battaglia M, Roncarolo MG: The Tregs' world according to GARP. Eur J Immunol 2009;39:3296300.

17 Schmidl C, Klug M, Boeld TJ, Andreesen R, Hoffmann P, Edinger M, Rehli M: Lineage-specific DNA methylation in T cells correlates with histone methylation and enhancer activity. Genome Res 2009;19:1165-74.

18 Lei J, Hasegawa H, Matsumoto T, Yasukawa M: Peroxisome proliferator-activated receptor and agonists together with TGF- $\beta$ convert human CD4+CD25- T cells into functional Foxp3+ regulatory T cells. J Immunol 2010;185:7186-98.

19 Ocklenburg F, Moharregh-Khiabani D, Geffers R, Janke V, Pfoertner S, Garritsen H, Groebe L, Klempnauer J, Dittmar KE, Weiss S, Buer, Probst-Kepper M: UBD, a downstream element of FOXP3, allows the identification of LGALS3, a new marker of human regulatory $\mathrm{T}$ cells. Lab Invest 2006;86:724-37. 
20 Pfoertner S, Jeron A, Probst-Kepper M, Guzman CA, Hansen W, Westendorf AM, Toepfer T, Schrader AJ, Franzke A, Buer J, Geffers R: Signatures of human regulatory $\mathrm{T}$ cells: an encounter with old friends and new players. Genome Biol 2006; 7:R54.

21 Don RH, Cox PT, Wainwright BJ, Baker K, Mattick JS: 'Touchdown' PCR to circumvent spurious priming during gene amplification. Nucleic Acids Res 1991;19:4008.

22 Baron U, Floess S, Wieczorek G, Baumann K, Grutzkau A, Dong J, Thiel A, Boeld TJ, Hoffmann P, Edinger M, Turbachova I, Hamann A, Olek $\mathrm{S}$, Huehn J: DNA demethylation in the human FOXP3 locus discriminates regulatory $\mathrm{T}$ cells from activated FOXP3(+) conventional T cells. Eur J Immunol 2007;37:2378-89.

23 Ronan A, Buiting K, Dudding T: Atypical Angelman syndrome with macrocephaly due to a familial imprinting center deletion. Am J Med Genet A 2008;146A:78-82.

24 Hochedlinger K, Plath K: Epigenetic reprogramming and induced pluripotency. Development 2009;136:509-23.

$\checkmark 25$ Allan SE, Broady R, Gregori S, Himmel ME, Locke N, Roncarolo MG, Bacchetta R, Levings MK: CD4+ T-regulatory cells: toward therapy for human diseases. Immunol Rev 2008;223:391-421.

26 Loser K, Hansen W, Apelt J, Balkow S, Buer J, Beissert S: In vitro generated regulatory $\mathrm{T}$ cells induced by Foxp3-retrovirus infection control murine contact allergy and systemic autoimmunity. Gene Ther 2005;12:1294-304.

27 Jaeckel E, von Boehmer H, Manns MP: Antigenspecific FoxP3-transduced T-cells can control established type 1 diabetes. Diabetes 2005;54:306-10.

28 Hansen W, Loser K, Westendorf AM, Bruder D, Pfoertner S, Siewert C, Huehn J, Beissert S, Buer $\mathrm{J}$ : $\mathrm{G}$ protein-coupled receptor 83 overexpression in naive $\mathrm{CD} 4+\mathrm{CD} 25-\mathrm{T}$ cells leads to the induction of Foxp3+ regulatory T cells in vivo. J Immunol 2006; 177:209-15.

29 Hansen W, Westendorf AM, Toepfer T, Mauel S, Geffers R, Gruber AD, Buer J: Inflammation in vivo is modulated by GPR83 isoform-4 but not GPR83 isoform-1 expression in regulatory $\mathrm{T}$ cells. Genes Immun 2010;11:357-61.

30 Reinwald S, Wiethe C, Westendorf AM, Breloer M, Probst-Kepper M, Fleischer B, Steinkasserer A, Buer J, Hansen W: CD83 expression in CD4+ T cells modulates inflammation and autoimmunity. J Immunol 2008;180:5890-7.

31 Ziegler SF: FOXP3: of mice and men. Annu Rev Immunol 2006;24:209-26. 